\title{
AGE-RELATED CHANGES OF PHOSPHOLIPIDS IN STERLET LIVER AND DORSAL MUSCLES
}

\author{
R. R. SULEIMANOVA', E. A. HUDZ², D. O. MELNYCHUK, L. H. KALACHNIUK \\ ${ }^{1}$ National University of Life and Environmental \\ Sciences of Ukraine, Kyiv; \\ e-mail: kalachnyuk_liliya@nubip.edu.ua \\ ${ }^{2}$ Palladin Institute of Biochemistry, National \\ Academy of Sciences of Ukraine, Kyiv
}

Study of phospholipids changes peculiarities in the liver and dorsal muscles of sterlet (Acipenser ruthenus Linnaeus) may be important to determine the etiology and pathogenesis of fatty liver. We established that the content of total phospholipids in tissues of the liver and dorsal muscles of three-year-old sterlet was less than for two-year-old fish by $15 \%$ and $20 \%(P \leq 0.01)$, respectively. The amount of phosphatidylcholine $(P \leq 0.05)$, phosphatidylethanolamine, phosphatidylserine $(P \leq 0.01)$, phosphatidylinositol $(P \leq 0.01)$ and cardiolipin in the liver of 3-year-old sterlet was lower than for the 2-year-old fish, while quantitative indices for lysophosphatidylcholine and sphingomyelin were slightly increased. Similarly, in the cells of the dorsal muscles, the amount of phospholipid components (except lysophosphatidylcholine) was decreased with age. A decrease in the amount of phosphatidylethanolamine and phosphatidylserine in the dorsal muscles of 3-yearold sterlet was significant. The major phospholipids respective distribution was stable, except for phosphatidylethanolamine and particularly sphingomyelin.

Key words: phospholipids, phospholipid fractions, liver and dorsal muscles of sterlet, age-related changes.

$\mathrm{S}$ terlet (Acipenser ruthenus) is the only sturgeon that lives in fresh water. It was put on the Red List of the International Union for Conservation of Nature as a "vulnerable species", while the Red Data Book of Ukraine treats it as “endangered species" [1]. In this regard, identifying the causes and molecular mechanisms of fatty liver and early death of sterlet is valuable both in order to conserve and farm industrially the fish $[2,3]$. This is most distinctly manifested in the annual cycle, during which lipid reserves may be redistributed between tissues and organs, with possible changes in dissimilation and assimilation of lipids, including phospholipids, depending on the dominant metabolic processes for this period [3, 4].

With this in mind, the aim of our research was to study the age-related changes of phospholipids contents in the liver and dorsal muscles of sterlet at the age of 2 and 3 years.

\section{Materials and Methods}

In our study, we used 10 sterlets (Acipenser ruthenus Linnaeus) of 300-400 g and 10 ones of 500$600 \mathrm{~g}$ aged two and three years, respectively. The fish were selected at the fishfarm "Osetr" in Ukrainka village of Obukhov district of Kyiv region in the spring of 2016. For biochemical analysis of phospholipid content, we used liver and dorsal muscles.

Lipids were extracted from homogenated tissues by the method of I. Folch et al. [5]. Phospholipids were separated by two-dimensional thin layer microchromatography on standard plates (Sorbfil, Russia) according to the method [6]. The phospholipid content was found from the amount of phosphorus in them determined using the molibdate reagent [7]. Specific reagents and purified standards were used to identify individual lipid fractions [8].

All interventions and slaughter of animals were carried out according to the national General Ethi-

(C) 2017 Suleimanova R. R. et al. This is an open-access article distributed under the terms of the Creative Commons Attribution License, which permits unrestricted use, distribution, and reproduction in any medium, provided the original author and source are credited. 
cal Principles of Experiments on Animals (Ukraine, 2001) [9] and the requirements of the European Convention on the Protection of Vertebrate Animals Used for Experimental and Other Scientific Purposes (Strasbourg, 1986).

Data are expressed as mean \pm SEM for at least 10 sterlets per age-group. Student's t-test was used for all analyses and values of $P \leq 0.05$ or $P \leq 0.01$ were considered to indicate statistically significant difference. All calculations were performed using the Microsoft Excel software for $t$-test analysis.

\section{Results and Discussion}

According to the data, we discovered that phospholipids content in tissues of the liver and dorsal muscles of sterlet was quantitatively decreased with age (Fig. 1-3). The content of total phospholipids in the liver and dorsal muscle tissues of three-year-old sterlet was less than of the two-year-old fish by $15 \%$ and 20\% (P $\leq 0.01)$, respectively (Fig. 1$)$. The total phospholipids content in the liver tissue of sterlet of different age groups exceeded the same indices for dorsal muscles (Fig. 1).

Membrane stability can be characterized by relevant qualitative and quantitative composition of their structural elements, changes in which point to

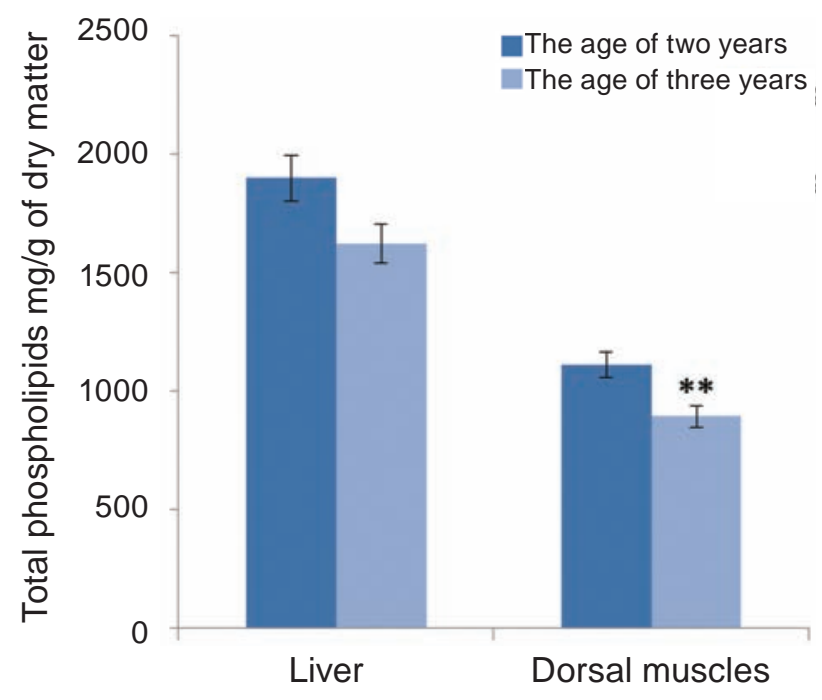

Fig. 1. Total phospholipids in tissues of sterlet of different age ( $m \pm S E M, n=10 ; * * P \leq 0.01)$

certain damage in membrane structures [10]. The amount of phosphatidylcholine $(P \leq 0.05)$, phosphatidylethanolamine, phosphatidylserine $(P \leq 0.01)$, phosphatidylinositol $(P \leq 0.01)$ and cardiolipin in the liver of 3-year-old sterlet was lower than for the 2-year-old fish, while quantitative indices for lysophosphatidylcholine and sphingomyelin were slightly increased (Fig. 2).

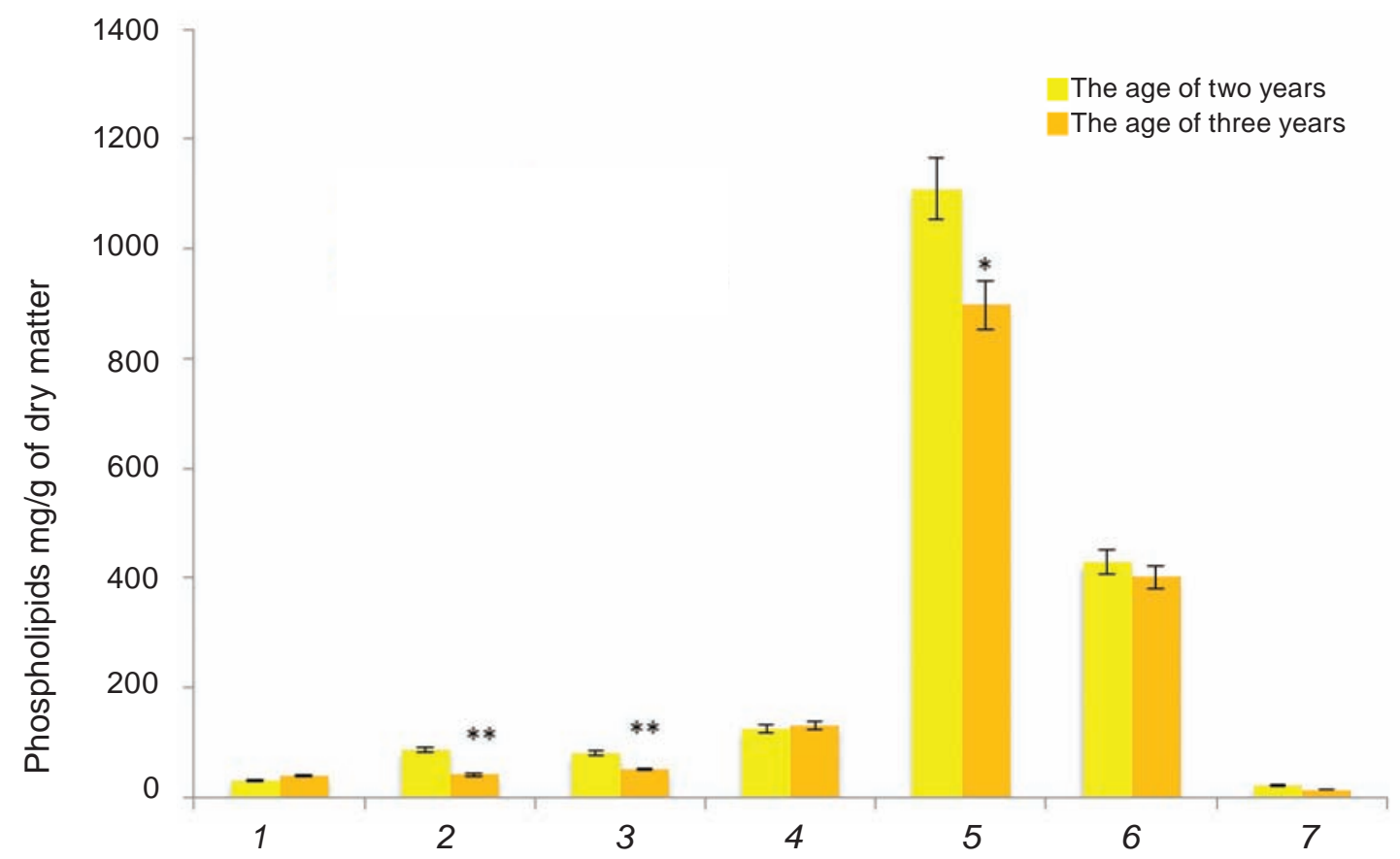

Fig. 2. Phospholipid content in liver of sterlet of different age: 1 -lysophosphatidylcholine, 2 - phosphatidylserine, 3 -phosphatidylinositol, 4-sphingomyelin, 5-phosphatidylcholine, 6 -phosphatidylethanolamine, 7 - cardiolipin ( $m \pm S E M, n=10 ; * P \leq 0.05 ; * * P \leq 0.01)$ 


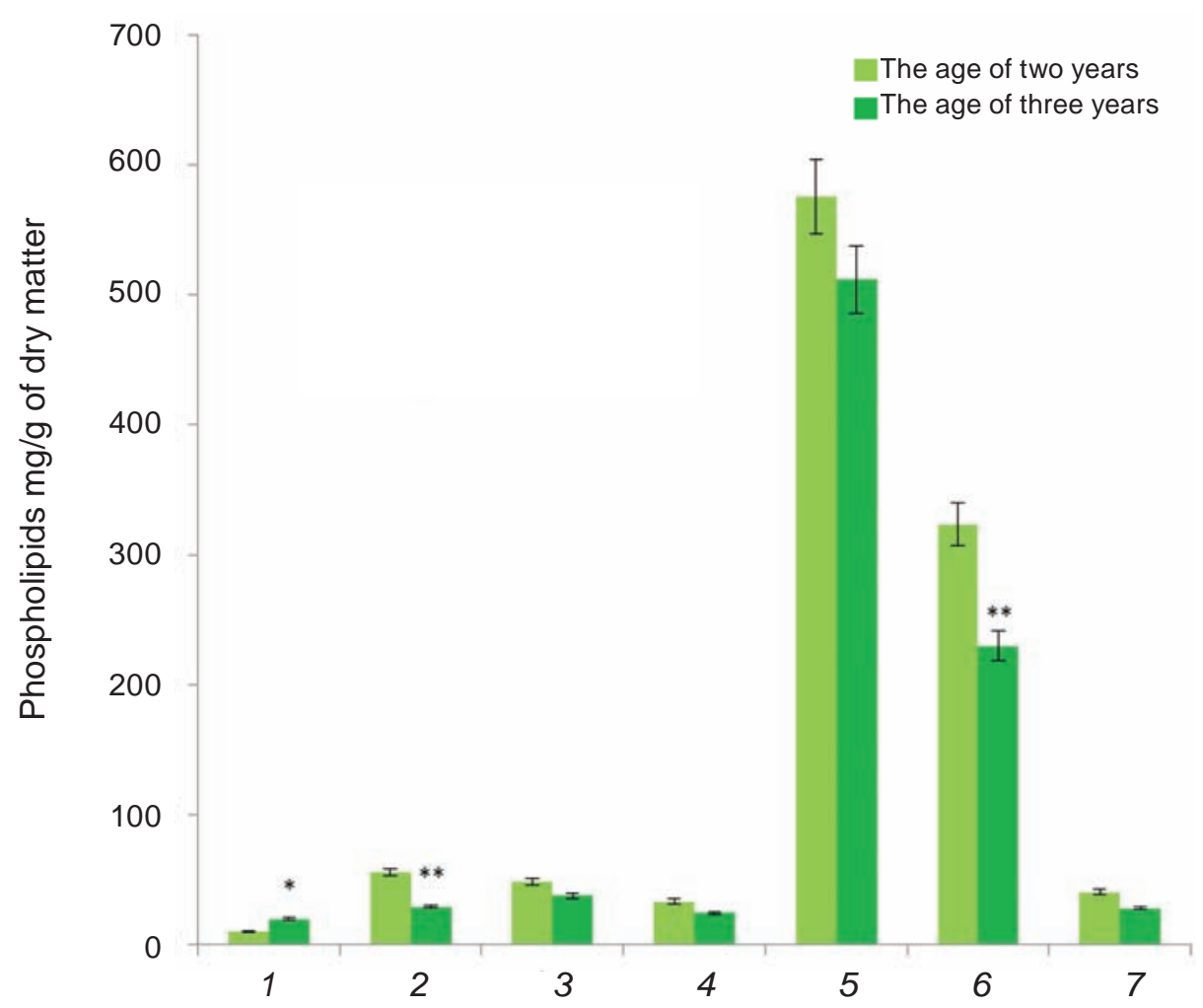

Fig. 3. Phospholipid content in the dorsal muscles of sterlet of different age: 1 -lysophosphatidylcholine, 2 phosphatidylserine, 3 - phosphatidylinositol, 4-sphingomyelin, 5-phosphatidylcholine, 6-phosphatidylethanolamine, 7 - cardiolipin ( $m \pm S E M, n=10 ; * P \leq 0.05$, ** $P \leq 0.01$ )

Similarly, in the cells of dorsal muscles, the amount of phospholipid components (except for lysophosphatidylcholine - product of phosphatidylcholine metabolism) decreased with age (Fig. 3). It should be noted that phosphatidylcholine and phosphatidylethanolamine are major phospholipids of cell membranes [10]. These phospholipids are metabolically linked and provide stabilization of plasmalemma and membranes of cell organelles. A reduction in their content in biological membranes can cause deviations in their ultrastructural organization, changes of biosynthetic processes, loss of individual units of metabolism, reduction of the vital energy-dependent processes, active transport of ions, etc. All this leads to increasing permeability of cell membranes and, therefore, to disruption of their transport functions which is generally known to be a universal feature of cell damage [2, 3, 11].

The quantitative ratio of phospholipid fractions in the liver and dorsal muscles in 2- and 3-year-old sterlets may indicate age-related redistribution of phospholipids between the tissues (Fig. 4). In general, while the amount of phospholipids generally decreased with age in the liver and dorsal muscles, their proportions in the tissues were stable (except for sphingomyelin, phosphatidylethanolamine and other non-determined minor phospholipid components).

Cardiolipin in the proportional distribution between tissues of the liver and dorsal muscles was the most stable parameter (Fig. 4) probably because it is the only phospholipid with immune properties. Cardiolipin also provides membrane permeability to ions; it is actively involved in the processes of oxidative phosphorylation and electron transport and serves as an inhibitor of DNA replication, regardless of its concentration [12].

A significant increase in sphingomyelin fraction in the dorsal muscles (Fig. 4) may indicate primarily its structural role in lipid micro-domains of the plasmatic membrane known as lipid rafts [13], which are possibly involved in the cascade of cell apoptosis [14].

Thus, we have established the trend to decreasing total phospholipids and their separate fractions except for lysophosphatidylcholine, while their distribution in the liver and dorsal muscle tissues of sterlet did not change with age (except for sphingo- 


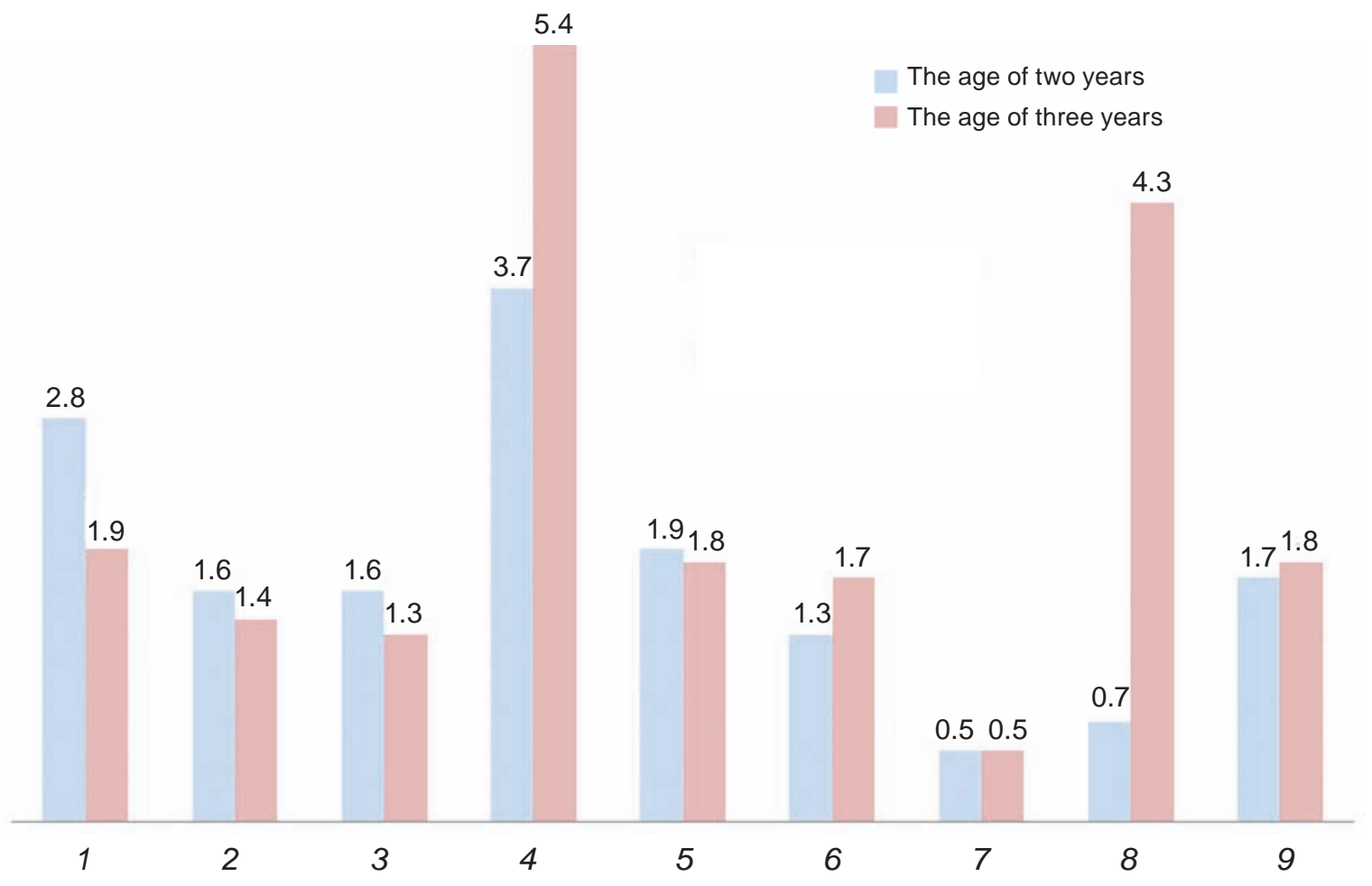

Fig. 4. Phospholipid components contents ratio in the liver tissue to ones in the dorsal muscle in two- and three-year-old sterlet [unit: (Liver phospholipids $\mathrm{mg} / \mathrm{g}$ dry matter)/(Muscle phospholipids $\mathrm{mg} / \mathrm{g}$ dry matter)]. 1 -Lysophosphatidylcholine, 2 -phosphatidylserine, 3 - phosphatidylinositol, 4 -sphingomyelin, 5 - phosphatidylcholine, 6-phosphatidylethanolamine, 7 -cardiolipin, 8-other undetermined minor phospholipids, 9 - total phospholipids

myelin and phosphatidylethanolamine). This can be used for theoretical substantiation and development of appropriate corrective feed additives and premixes.

\section{Acknowledgements}

The authors are grateful to the fishfarm "Osetr" in the village of Ukraiinka (Obukhov district of Kyiv Region) for providing biological material for research.

\section{ВІКОВІ ЗМІНИ ФОСФОЛІПІДІВ В ПЕЧІНЦІ ТА СПИННИХ М'ЯЗАХ СТЕРЛЯДІ}

Р. Р. Сулейманова 1 , С. А. Гудзь², Д. О. Мельничук, Л. Г. Калачнюк ${ }^{1}$

\footnotetext{
${ }^{1}$ Національний університет біоресурсів і природокористування України, Київ; e-mail: kalachnyuk_liliya@nubip.edu.ua; ${ }^{2}$ Інститут біохімії ім. О. В. Палладіна НАН України, Київ
}

Вивчення специфічних змін фосфоліпідів у тканинах печінки і спинних м'язів стерляді
(Acipenser ruthenus Linnaeus) може мати важливе значення для визначення етіології і патогенезу жирового гепатозу, що зустрічається в цього виду риб в умовах штучного вирощування. Встановлено, що вміст загальних фосфоліпідів у тканинах печінки і спинних м'язів стерляді трьох років був меншим, ніж у дворічної риби на 15 і 20\% $(P \leq 0,01)$ відповідно. Кількість фосфатидилхоліну $(P \leq 0,05)$, фосфатидилетаноламіну, фосфатидилсерину $(P \leq 0,01)$, фосфатидилінозитолу $(P \leq 0,01)$ i кардіоліпіну в печінці трирічної стерляді була нижчою, ніж для дворічної риби, в той час як кількісні показники для лізофосфатидилхоліну i сфінгомієліну були трохи збільшеними. Аналогічним чином у клітинах спинних м'язів кількість компонентів фосфоліпідів (за винятком лізофосфатидилхоліну) зменшувалась із віком. Зменшення фосфатидилетаноламіну i фосфатидилсерину в спинних м'язах трирічної стерляді було вірогідним. Кількість основних фосфоліпідів, за винятком лізофосфатидилхоліну, із віком знижувалась у 
клітинах печінки і спинних м'язах. У той самий час зберігалася пропорція їх розподілу між тканинами, крім фосфатидилетаноламіну і особливо сфінгомієліну.

Ключов в с слова: фосфоліпіди, фосфоліпідні фракції, печінка та спинні м'язи стерляді, вікові зміни.

\section{ВОЗРАСТНЫЕ ИЗМЕНЕНИЯ ФОСФОЛИПИДОВ В ПЕЧЕНИ И СПИННЫХ МЫШЦАХ СТЕРЛЯДИ}

\author{
Р. Р. Сулейманова 1 Е. А. Гудзь ${ }^{2}$, \\ Д. А. Мельничук, Л. Г. Калачнюк
}
${ }^{1}$ Национальный университет биоресурсов и природопользования Украины, Киев; e-mail: kalachnyuk_liliya@nubip.edu.ua;
${ }^{2}$ Институт биохимии им. А. В. Палладина НАН Украины, Киев

Изучение специфических изменений фосфолипидов в тканях печени и спинных мышц стерляди (Acipenser ruthenus Linnaeus) может иметь значение для определения этиологии и патогенеза жирового гепатоза, встречающегося при искусственном выращивании этого вида рыб. Установлено, что содержание общих фосфолипидов в тканях печени и спинных мышцах стерляди трех лет было меньше, чем у двухлетней рыбы на 15 и $20 \%(P \leq 0,01)$ соответственно. Количество фосфатидилхолина $(P \leq 0,05)$, фосфатидилэтаноламина, фосфатидилсерина $(P \leq 0,01)$, фосфатидилинозитола $(P \leq 0,01)$ и кардиолипина в печени трехлетней стерляди было ниже, чем у двухлетней рыбы, в то время как количественные показатели для лизофосфатидилхолина и сфингомиелина были немного увеличены. Аналогичным образом в клетках спинных мышц количество компонентов фосфолипидов (за исключением лизофосфатидилхолина) уменьшалось с возрастом. Уменьшение фосфатидилэтаноламина и фосфатидилсерина в спинных мышцах трехлетней стерляди было достоверным. Количество основных фосфолипидов, за исключением лизофосфатидилхолина, с возрастом снижалось в клетках печени и спинных мышцах. В то же время сохранялись их пропорции распределения между тканями, кроме фосфатидилэтаноламина и особенно сфингомиелина.
К л ю че в ы е с л о в а: фосфолипиды, фосфолипидные фракции, печень и спинные мышцы стерляди, возрастные изменения.

\section{References}

1. Acipenser ruthenus (Sterlet). Regime of access: http://dx.doi.org/10.2305/IUCN.UK.2010-1. RLTS.T227A13039007.en.

2. Vaskovskiy VE. Lipids. Soros Educat J. 1997; (3): 32-37.

3. Hrytsyniak II, Smolianinov KB,Yanovych VH. Lipid metabolism in fish. Lviv, Triad plus, 2010. 335 p. (In Ukrainian).

4. Moffat RG, Stamford B. Lipid metabolism and haelth, Taylor and Francis, 2006. 377 p.

5. Folch J, Lees M, Sloane Stanley GH. A simple method for the isolation and purification of total lipides from animal tissues. $J$ Biol Chem. 1957; 226(1): 497-509.

6. Svetashev VI, Vaskovsky VE. A simplified technique for thin-layer microchromatography of lipids. J Chromatogr. 1972; 67(2): 376-378.

7. Vaskovsky VE, Kostetsky EY, Vasendin IM. A universal reagent for phospholipid analysis. J Chromatogr. 1975; 114(1): 129-141.

8. Keits M. Techniques of lipidology. Isolation and identification of lipid analyses. Moscow: World, 1975. 322 p. (In Russian).

9. Reznikov $\mathrm{OH}$. General ethical principles of animal experimentation. First National Congress on Bioethics. Endocrinol. 2003; 8(1): 142-145. (In Ukrainian).

10. Orel NM. Lipid biochemistry. Minsk, 2007. 37 p. (In Russian).

11. Gula NM, Margitich VM. Fatty acids and their derivatives in pathologic states. Kyiv: Naukova dumka, 2009. (In Ukrainian).

12. Cardiolipin (phosphatidylglycerol). Biology and Medicine. Regime of access: http://medbiol.ru/ medbiol/biochem/001cd687.htm.

13. Quinn PJ. Sphingolipid symmetry governs membrane lipid raft structure. Biochim Biophys Acta. 2014; 1838(7): 1922-1930.

14. Brauweiler AM, Goleva E, Leung DY. Th2 cytokines increase Staphylococcus aureus alpha toxin-induced keratinocyte death through the signal transducer and activator of transcription 6 (STAT6). J Invest Dermatol. 2014; 134(8): 21142121. 